\title{
Permanent Representations to the European Union ${ }^{\mathrm{i}}$
}

\begin{abstract}
Despite the burgeoning literature devoted to the European Union, there has been little scholarly attention devoted to the role of EU Permanent Representations and the degree to which they act as a linkage between member states and EU institutions. This article consequently attempts to address this gap by focusing upon the structures, tasks and activities of Permanent Representations.
\end{abstract}

Of all European capitals, Brussels has the largest population of diplomats. It is the official seat of two major EU institutions, the Council of Ministers ${ }^{\mathrm{ii}}$ and the European Commission, and while Strasbourg is the official seat of the European Parliament, ${ }^{\text {iii }}$ Brussels is where the Parliament's Committees conduct their work. Besides these institutions, it is also the home of the North Atlantic Treaty Organisation (NATO) and the Western European Union (WEU), while there are also the normal Embassies accredited to the Belgian Government that EU member states keep separate from their Permanent Representation. Finally, there are the Missions of non-member states to the EU, which in many instances are different from that nation's Embassy to Belgium. Some of those non-members have proceeded to be admitted to the EU, at which stage these Missions have become Permanent Representations, a status reflected by the greater number of staff that are necessary to cope with the extra workload.

Of the diplomatic establishments that are accredited to these bodies, EU Permanent Representations tend to be the largest, though the differing membership composition of these organisations means that not all EU member states have a representation at each of them. The status attributed to the EU Permanent Representation will therefore differ depending on 
the nation concerned. For example, the British and French Permanent Representations to the EU have a comparable ranking to their Delegations to NATO and the United Nations (UN). They are also more important than representations to smaller organisations, such as Delegations to the Organisation for Economic Co-operation and Development (OECD) in Paris or Missions to the international organisations in Geneva. This article accordingly examines the role played by Permanent Representations within the EU and demonstrates the extent to which they act as a linkage between member states and EU institutions.

\section{Structure}

Permanent Representations are basically the Brussels arm of national Government Departments, with Permanent Representatives predominantly coming from their countries' Foreign Service. Most staff nevertheless come from a range of Government Departments, including Trade and Industry, Finance, Employment and Agriculture. In seconding staff to Permanent Representations, Government Departments choose people of good quality. ${ }^{\text {iv }}$ This is partly because of their effectiveness while they are in Brussels; Governments require skilled individuals that are able to negotiate effectively in meetings. Many of these individuals will have already obtained experience of EU affairs from a domestic context, such as in the Ministry of Agriculture. But these officials obtain far more detailed knowledge of the subject matter while working in the Permanent Representation in Brussels. This very structure of the Permanent Representation, comprising staff from a whole range of Government Departments, marks this diplomatic posting from all others. This is because other Foreign Office postings, such as Embassies, are primarily comprised of career diplomats. ${ }^{\mathrm{v}}$ The differing composition of a Permanent Representation consequently means that it is not as easy to establish a coherent team and hence the management skills of the Permanent Representative will play a major factor in determining operational effectiveness. 
For some, a post in a Permanent Representation can become a stepping stone to a job within an EU institution, as is equally true for officials in those Government Departments that are closely involved with EU affairs. That is not to say that closer contact with the EU institutions always leads to a pro-European outlook. Appointments are not just made with a view to the period of secondment (normally 3-5 years), but also with a view to providing a broad structure of career training for officials marked out for senior positions. The reason for doing this is one of pragmatism. This is because it is obviously a great help to those who are involved in EU policy-making to have domestic contacts that are familiar with operational procedures in Brussels. It reduces the amount of time spent explaining matters of policy co-ord ination and ensures there is an effective 'knit' between the domestic and EU level. One notable effect of these appointments has been the dramatic increase in the number of domestic staff who have obtained first-hand experience of policy-making in the EU. In conjunction with the sheer number of staff who support Permanent Representations on a daily basis, this has led to an erosion in the traditional distinction between domestic and international policy-making, producing a trend towards the Europeanisation of domestic governance.

Regarding the actual composition of Permanent Representations, each member state is required to appoint a Permanent Representative by the EU Treaty. $\mathrm{He}-\mathrm{a}$ woman has yet to hold the position - has the rank of Ambassador with his staff having diplomatic status. And while the EU Treaty only requires Permanent Representatives to meet as a Committee (COREPER) 'for preparing the work of the Council and for carrying out the tasks assigned to it by the Council', ${ }^{\text {vi }}$ the workload does necessitate a large staff. The simple reason for this is that from the early days of the Community it was evident that the job of 'preparing the Council's work' was too great for one Committee because the Council meets in many 
different formats. A Committee of Deputy Permanent Representatives was therefore created to assist with the increasing workload.

The need to have a large staff permanently based in Brussels is often reinforced by the distance of national Government from the EU capital. The only nation that could be exempted from this rule is Belgium because its central Government officials are located in Brussels and can assist the Permanent Representation. But the Belgian Permanent Representation does not by any means have the smallest staff of all member states. One of the reasons for this is the importance attributed to teamwork in Permanent Representations, with staff often having to respond quickly to negotiating positions. It is therefore a great benefit to have a permanent group of officials, rather than constantly drawing together a disparate group depending on the issue in question. (Permanent Representations also receive additional support from national capitals.)

The size of Permanent Representations depends on the resources available to each member state and the way in which it wants to organise its relations with the EU. Greece and Portugal have traditionally had one of the largest staff of EU Permanent Representations. The reason for this centres on the EU Committees and Working Groups that are composed of officials from member states' Permanent Representations and national capitals. ${ }^{\text {vii }}$ The sheer number and frequency of Committee meetings means that those nations that are at a greater distance from Brussels are less able to staff their Permanent Representations on a daily basis. And while the EU budget does attempt to create a level playing field by providing travel costs for a limited number of those officials coming from national capitals, Greece and Portugal have maintained relatively larger Permanent Representations because of the lengthy journey time and the relative infrequency of flights from the ir national capitals. The close proximity of France, Germany and Britain enables them to draw at short notice on the expert advice within national capitals. The staffing levels of the Permanent Representations of these 
countries can therefore be kept at a relatively lower level. (Staff who commute come under the authority of the Permanent Representative.)

Of other points, it is important to distinguish between national staff based in Brussels and those locally engaged. Thus, while UKRep note that their normal staff size is around 100, the annual Guide to the Council of the $E U$ informs us that in 1998 there were 52 staff within UKRep who were engaged in specific work on behalf of Britain. The difference being that the larger total includes secretarial and other administrative support, while the Council guide only refers to officials dealing with policy. Those non-administrative staff are generally divided into various sections to deal with the policy areas that are dealt with by the EU. In the case of UKRep, staff are divided into the following broad sections (a typical pattern for other member states):

- Political affairs. This section examines such issues as the institutional reform of the EU, Agenda 2000, devolution, openness and transparency and the future development of the EU. It also supervises those staff in the Permanent Representation that deal with the press, commercial activities and the management of the office.

- Institutions. This section embraces the many policies that affect the EU, including relations with other institutions such as the European Parliament, as well as ensuring that British nationals are sufficiently represented in the staff of the institutions.

- Agriculture and fisheries. This section serves the Agriculture and Fisheries Councils as well as the Internal Market Council on those matters that relate to food.

- Industrial policy, research and development, the internal market and transport. This section tends to assist technical Councils in the area of energy policy, technology, industry and the Single Market. And because of the nature of this subject, the section makes direct contact with the Commission on policy matters of competition and state aid. 
- Social affairs, regional policy, environment, health and culture. This section provides assistance to Council meetings that deal with culture, education, the environment, health, youth and social affairs. It additionally advises on regional policy, including assisting with matters relating to the structural funds and advising those UK regional offices that are involved with EU policy.

- Economic affairs, finance (including the EU budget) and taxation. This section includes all the issues that are dealt with in the Economic and Finance Ministers (Ecofin) and Budget Councils, as well as Economic and Monetary Union(EMU); fraud prevention; the finances of the Community; and customs, financial service questions and tax.

- External affairs, including worldwide trade policy, development policy, enlargement and the EU's common foreign and security policy (CFSP). This section services the General Affairs and Development Councils as well as the Article 113 Committee (Trade Policy) and the Political Committee.

- Legal affairs. Apart from providing advice on the whole range of EU affairs, this section also includes justice and home affairs, which deals with EU co-operation in matters concerning frontiers, immigration, visa policy and asylum policy, as well as co-operation in police, drugs and judicial matters.

The above organisational structure reflects the changes that the EU has undergone in recent years, with an increase in the size and staff of Permanent Representations mirroring the growth of EU activities. Many of the above areas of competence are recent developments, whereas activity in the early years was focused on such topics as agriculture, competition policy, external trade, finance and budgetary affairs. To take an example, the expansion in the European Parliament's powers through Article 6 of the Single European Act (co-operation procedure), Article 189b of the Maastricht Treaty (co-decision procedure), and 
the further widening of its competencies under the Amsterdam Treaty (Article 251), has increased the status and importance of the European Parliament in the EU policy process whereby over $80 \%$ of all decision-making within the EU is now subject to the co-decision procedure. The direct impact of this is that the European Parliament is now a co-legislator with the Council on the majority of EU law, thereby requiring member states to pay just as much attention to the views of the European Parliament (and individual members) as it does to negotiations within the Council.

The reality of this change in the EU decision-making process is that the relationship between member states and the European Parliament has taken on a more substantial and important role in recent years. To this end, member states therefore have to spend a great deal more time taking into consideration the views of the European Parliament in the framing of policy because the views of Members of the European Parliament matter. This has an impact on negotiators based in Permanent Representations as well as those officials based in domestic departments who deal with European policy because governments can no longer spend the majority of their efforts lobbying to pursue national interests in Council negotiations. By contrast, it is just as important that governments are able to influence the European Parliament when policy documents are passed to the Parliament. To this end, member states do not just react to the European Parliament's proposals but crucially are proactive in lobbying for objectives from the outset. Success is nevertheless heavily influenced by the relative strength of the member state within the European Parliament. In this context, the effectiveness of the British system of policy co-ordination on European affairs does not always transcend into having a significant input to the European Parliament, whereas it does count in Council negotiations. Germany, by contrast, partially by virtue of having the largest number of MEPs (99), is often more able to exercise its views within the European Parliament. 
In contrast to the example of the European Parliament, other changes to the EU's competencies do not always represent the creation of new policies, but merely reflect a move away from national control. For instance, while a common foreign policy has become a focus of responsibility for Permanent Representations in recent years, it had been on the EU agenda for some time, being previously referred to as 'political co-operation' and solely dealt with by national governments. The fact that Permanent Representations now have input in this area of EU business is reflective of the move away from intergovernmental action towards a more co-ordinated European policy. And although this trend was first evidenced in the Single European Act (part II), it was not until the Maastricht Treaty (Title V) that foreign policy was firmly located within the scope of EU business, a development further refined by the Amsterdam Treaty. It is therefore evident that the ever-changing nature of the EU has a dramatic impact on the structure and role of Permanent Representations within the EU policy process.

\section{Tasks}

The high status of Permanent Representations directly correlates with their tasks. These both mirror and differ from traditional diplomatic duties associated with Embassies and consulates, while also resembling and differing from the work of other Delegations and Missions. The very term 'Permanent Representation' is imposed by the EU Treaties ${ }^{\text {viii }}$ and is demonstrative of the 'permanent' nature of the negotiations. While Delegations to the UN and Missions to the OECD are forums of constant negotiation, the scope of their work is not as intensive or as constant. Officials in EU Permanent Representations are involved in regular scheduled meetings that deal with a whole range of topics from agriculture to transport and social affairs to foreign policy. It is true that other international organisations also have regular meetings, some of which have a greater focus on foreign and defence policy 
(NATO). But the sheer breadth and depth of the EU's activities are not mirrored by any other organisation. An important distinction to draw between EU Permanent Representations and other diplomatic postings, including normal Embassies, is that the constant negotiation of legal texts within the EU reflects the different status of this body.

The intensity of negotiation activity within Brussels, and the ever-changing nature of the EU's membership and areas of competence, means it is vital for member states to maintain staffing levels in their Permanent Representations so as to be able to respond to these policy developments. While developments in travel and communications have been advanced as a reason for downplaying the importance of the resident Ambassador, this has not been the case for Permanent Representations. Thus, although technological improvements have eased the burden of travel for those officials who supplement the work of Brussels-based negotiators, in no sense has this reduced the burden of direct representation. To take an example, secure video conferencing is now a common means of contact between Permanent Representations and national capitals, thereby reducing the need for domestic officials to visit Brussels and vice versa. But this is not a portable procedure and can only be used for scheduled meetings. It therefore does not reduce the role of those domestic officials involved in EU-level negotiations, or replace the necessity for members of the Permanent Representation, including the Permanent Representative, to visit the national capital on a regular basis so as to brief Government. Video-conferencing is thus another item in a negotiators tool kit and does not replace the importance of one-to-one discussions. This closeness between Permanent Representations and national capitals is significantly not a feature that is common for all diplomatic postings. It is uncommon for Ambassadors to make regular (weekly) trips to their national capital. The only exception to this rule is that of Delegations to the UN, but even they are more divorced from national capitals and do not have the same constant and direct input into the policy that is formulated by Government. 
The end product of these developments is that the role of the staff attached to Permanent Representations, including the Permanent Representative, has become more crucial as national capitals demand greater information on negotiating dilemmas and Permanent Representations pursue negotiating instructions. Such instructions are not always clear and can hinder the ability of the staff in the Permanent Representation to adequately negotiate on behalf of Government, with a concurrent reduction in that nation's influence in particular debates. The other extreme to this scenario is that those instructions, which are provided, might be so clear as to eliminate any room for manoeuvre within the concerned negotiation (being often reflective of the British position). The trick is for a Government to provide its negotiators with a suitable balance of clarity and room to adapt the national position depending on the course of the discussions. (Such changes of plan usually take place within prior agreed fallback positions.) EU negotiations are therefore a complex affair, which impinge on a wide range of Government interests and necessitate clear lines of communication both within Government and between it and the institutions of the EU. In the midst of this battleground, the Permanent Representation plays a vital logistical and supporting role. This function can be particularly important when there are unclear instructions from Government, as is often the case for Germany, where domestic co-ordination problems have had a tendency to result in multiple or conflicting sets of instructions. In this sense, the Permanent Representative has been known to play the negotiating viewpoints of one Ministry off against the other in an effort to move the debate towards the middle ground. In this context, instructions that are unclear or conflicting might provide enough freedom to create a margin for manoeuvre in negotiations.

The outcome of such a focus on Brussels-based negotiations has been the growing importance attached to multilateral and bilateral diplomacy. And while this has not resulted in a downgrading in the staffing of member states Embassies in all EU nations, there has 
nevertheless been a move towards more concentrated discussions within Brussels. This is a development that is not just the preserve of the EU, but other bodies such as NATO. On some debates this can lead to a complicated set of affairs, with, for instance, EU Permanent Representatives discussing CFSP issues and NATO Ambassadors discussing NATO strategy. The fact that these subjects touch on essentially the same points does not mean that there is always close contact between the two bodies. This was certainly the case during 1991 when Permanent Representatives were negotiating on, among other points, the CFSP elements of the Maastricht Treaty and NATO Ambassadors were reviewing NATO strategy. Both of these debates took place in relative isolation. And while this type of situation may no longer happen, one of the reasons for this was that not all EU member states were part of NATO, while there were also NATO states, such as Canada and the US, that are not part of the EU. Moreover, if those two bodies had met, then some EU member states (such as France) might have been concerned that the Atlanticism of NATO could have percolated into EU texts.

\section{Areas of activity}

So what then do EU Permanent Representations exactly do? They expend their greatest effort by lobbying and negotiating on behalf of national capitals and informing the latter of the extent to which EU activities affect them. ${ }^{\text {ix }}$ Here, the basic procedure is that once a national policy has been established, Permanent Representations are required to negotiate, or at least assist in negotiating. It is generally desirable that the Permanent Representation has an input into the process of policy formulation, as well as the revision of that policy in light of other developments, including changes in the negotiating position. To that extent, close contact is necessary with all the EU institutions, especially the Commission and the European Parliament, as well as other Permanent Representations. But the task of Permanent Representations also extends to representing the concerns of national business interests and 
domestic Parliamentarians. Some work is not dealt with by Permanent Representations, including issuing passports and providing general assistance to home nationals. That is done by Brussels-based Embassies.

Of the functions that are dealt with by Permanent Representations, it is possible to list five. The first is that of an information gatherer. That is to discover what proposals are being worked upon in the Commission, and where appropriate, lobby for changes. This is especially important as the Commission sometimes takes care to keep its work secret until it has decided on a proposal, while at the other extreme it sometimes floats ideas in general terms with the view of obtaining reactions from Governments and interested parties, such as business groups and trade unions. Beyond this passive intelligence function, it is clear that a member state can make a major gain if it even modestly moves a proposal in its own direction before it formally appears. The ability to do this depends on the negotiating issue and the level of experience and knowledge offered by a member state. Success in this area depends on Government Ministers having clear objectives as to what is achievable and consequently a Government that does not provide its negotiators with clear instructions is unlikely to influence policy. Nevertheless, some policy areas lend themselves more to pre-negotiation influence than others do. Technical points are of particular relevance. This is because it is clear that officials in other member states can have specific knowledge to offer, much of which is often welcomed. Obviously, the ultimate level for contact is the Commissioners themselves, and while they are supposed to work in accordance with the interests of the EU as a whole, they are open to reasoned argument. It is therefore sensible for Governments to advance factual analysis on the particular negotiating issue.

The second function is that of information provider. This involves two tasks, the first of which is to brief Ministers who attend meetings of the Council, with particular attention on negotiating tactics, such as the negotiating strategies adopted by member states, the European 
Commission and the European Parliament. The second task is to ensure that national Members of the European Parliament are aware of the Government's position, as well as providing extra assistance as and when required. The role of information provider takes many formats, including weekly trips by the Permanent Representative to brief Government Ministers and officials on developments at the EU level. Such meetings often take place on a Friday because commitments in Brussels are generally much lower.

Related to this point, the third function that a Permanent Representation faces is that of policy formulation, whereby it assists in putting together national policy towards EU issues and proposals. This also includes having to adjust to policy as the negotiating situation develops. Permanent Representations also assess or predict the actual (as well as the potential) reactions of other member states and EU institutions, especially the Commission and European Parliament. Much of this involvement in policy formulation takes place in national capitals, whereby staff from the Permanent Representation briefs Government Ministers and officials. The specific system for dealing with policy input from Permanent Representations varies in each member state, though the eventual outcome is with a view towards a co-ordinated national negotiating position.

In this context, the very size of Luxembourg has meant that there has been little need for elaborate methods of policy co-ordination, with the Permanent Representation often acting in an independent manner, as was the case during the negotiations that led to the Maastricht Treaty. The UK, by contrast, has a more formal system of policy co-ordination centred on the European Secretariat of the Cabinet Office, the role of which is to hold meetings to establish EU negotiating objectives. But this is still a relatively small-scale operation with no more than 20 staff, although some 200 to 250 meetings of officials are held by the European Secretariat per year. In comparison, its counterpart in France, the SGCI (Secrétariat général du comité interministériel pour les questions de co-opération économique 
européenne) has over 100 staff, though it primarily deals with economic points. ${ }^{\mathrm{x}}$ And while these bodies are relatively non-political and reflect the interests of Government as a whole, the same cannot be said for Germany, where the Chancellery in Bonn essentially exists to inject a view from the Chancellor through a policy-making role, partly a result of the loosely co-ordinated nature of European policy within Germany. Indeed, Sir Michael Butler, a former Permanent Representative himself, considered '...the Germans were always badly co-ordinated'. ${ }^{\mathrm{i}}$

The fourth function is that of an information conductor. This role is of importance in linking EU institutions and national Governments because the former does not always know where the exact point of contact is within national Governments for addressing a communication. Permanent Representations also assist national organisations to contact the Commission, European Parliament or other EU institutions for lobbying purposes. Permanent Representatives are therefore essentially a directory of contacts. In this context they provide an information service at the EU level to the various institutions and member states and at the domestic level to the various tiers of government and business interests, as well as anyone else who wishes to establish a contact within the European Union. The staff of a Permanent Representation will thus have as many contacts with their counterparts from the other member states as they will have with the institutions of the EU. This contrasts with the usual contacts of a normal Embassy, which are mainly with the concerned Government and far less with the other Embassies. (Some Embassies do, however, have a traditional tendency for closeness, such as Britain and America.)

The fifth and some would say most crucial function, is that of a negotiator. The staff of a Permanent Representation negotiate at official level in line with instructions given by national Governments. This can be done either through informal contacts or the formal process of negotiating in Committees of the Council, the staff of which can be composed of 
officials from Permanent Representations and national capitals. Those that are staffed by the latter include the Monetary Committee (high level officials from Finance Ministries and national Central Banks); the Article 113 Committee (officials in charge of trade policy); and the so-called Political Committee (Foreign Policy experts). The practice for the rest of the Committees varies (except COREPER), though even the largest Permanent Representations could not cope with all of the official-level meetings and requires additional support from home. An extreme example is that of agriculture, where the annual number of meetings in Brussels attended by Agriculture officials is often not far short of 1000. (This is a special case because agriculture is an extremely complex topic.)

But while this negotiating role has traditionally taken place within the Council, Permanent Representations now have to invest a great deal of effort in ensuring that national views are advanced within the European Parliament. This is both because the European Parliament has a co-legislating role with the Council on a majority of European law, and because the relative political weight of the Parliament has increased, demonstrated by the 1999 resignation of the European Commission that was led by Jacques Santer. The outcome of these developments is that member states need to lobby and negotiate with the officials and members of the European Parliament on a regular basis. And just as Permanent Representations are a pivot in terms of the relationship between member states and the Commission, they are central to the ever-increasing importance of the linkage with the Parliament.

The very ability to carry out these five functions is, however, greatly determined by the degree to which national capitals exercise leadership within the EU and the quality of the instructions provided to Permanent Representations. In this context, the British system of national policy co-ordination has tended to produce a well co-ordinated and detailed set of instructions for its negotiators in Brussels. But while this method has had the advantage of 
ensuring that there is coherence in the government's approach to EU negotiations, the setting of pre-determined policy guidelines often limits the room for manoeuvre at the EU level. Added to this, political leadership within the EU has become an increasingly important factor in the ability of a member state to influence policy decisions within the European Parliament.

In contrast to the British method of policy co-ordination, other member states, including France and Germany often produce less constraining negotiating instructions for their Permanent Representations. More importantly, however, their relative commitment to the EU provides their negotiators with a greater degree of flexibility at the EU level because there is not the same need to constantly authorise policy decisions taken with their national capitals. Moreover, the existence of political leadership has the additional benefit of being able to exercise influence when lobbying the European Parliament.

\section{COREPER}

As for COREPER, there are in fact two COREPER's, one comprising the Permanent Representatives and the other their Deputies. It is somewhat confusing that they are respectively named COREPER 2 and COREPER 1, with the former having responsibility for the Foreign Affairs Council, ${ }^{x i i}$ the Economic and Finance Council, the Budget Council, the Development Council and the Justice and Home Affairs Council. COREPER 1 covers the rest, including Culture, Education, Energy, Environment, Industry, Research, Telecommunication, Tourism and Social Affairs. Apart from holiday periods, meetings take place at least once a week, with COREPER 1 tending to have the greater number. Otherwise, because the Foreign Affairs Council prepares the work of the European Council, Permanent Representatives are also involved in this work. There is one exception to the rule that COREPER prepares all the meetings of the Council. This is because it was agreed at an early stage that neither Permanent Representatives nor their Deputies should have to get 
involved with the extremely complicated Common Agricultural Policy (CAP). Thus, a separate body, the Special Committee for Agriculture (SCA) was established with the responsibility of preparing meetings of the Agriculture Council for those items that relate to the CAP. While some countries, such as the UK, staff the SCA from Permanent Representations, others do this from national capitals. Other items discussed by the Agriculture Council are prepared by COREPER 1.

These various Committees prepare points to a state where they can be finally decided, or at least to a point where Ministers can discuss them in a constructive manner. Minor issues can be wholly agreed in Working Groups, COREPER, the SCA, or agreed subject to contrary votes that are not sufficient to prevent adoption. These issues, which are referred to as 'A Points' in Council jargon, then go on to the Council agenda as items for adoption without discussion (any Minister at the Council is able to object to that procedure being followed). While this type of situation is sometimes portrayed as Euro-friendly officials conspiring to keep their political masters in ignorance, the reality is that officials act at all times under instructions (though some have more freedom to be flexible). The very reason why this type of agreement takes place is that not all EU business is of a controversial nature and it is sensible that Ministers in Council should spend as much time on those matters that really do need their attention. Topics to be discussed at Council meetings are identified as 'B Points' instead of the 'A Points' which signal those issues that have been agreed to.

These functions are not the sole preserve of the Permanent Representation, and are exercised in a co-ordinated manner with officials based in national capitals. Home-based officials also have their own contacts with opposite numbers in the Commission and other EU institutions such as the European Parliament. One can therefore imagine that EU negotiations can often be a complex affair, with there being involvement from a range of Government Departments. A major negotiation is likely to entail the establishment and use of bilateral 
contacts between officials from national capitals and/or their Minister by telephone. It is also likely that those central to the negotiation will make visits to the interested parties, such as to pertinent Ministers and officials in other member states, the European Commission, and officials and members of the European Parliament. At those visits, Ministers are likely to be assisted by their own officials and advisors, while ministerial attendance at Council meetings merits the additional support of the Permanent Representative. In all of these areas, the particular level of involvement will depend on the issue in hand, on the working practices adopted by different governments and on the personalities involved. As a general rule, Brussels-based staff are in the best position for developing contacts with the Commission, Council Secretariat, and the European Parliament, the importance of which has dramatically increased since the Amsterdam Treaty of 1997. It is also the case that the Permanent Representative (and/or their Deputies) might be able to use personal contacts with their counterparts from other member states with greater ease and effectiveness than can officials in separate national capitals.

\section{The Presidency}

The above information has detailed the regular areas of activity that Permanent Representations are concerned with. But in addition to these tasks, each Permanent Representation takes its turn in having the responsibility of organising the EU Presidency, with Deputy and Permanent Representatives also having to chair meetings of their fellow negotiators. Ministers of the State holding the Presidency likewise have to chair meetings of the Council. This is also the case for those officials that man the various EU Committees and Working Groups (except those chaired by the Commission). A significant addition to these tasks has been the increased number of meetings between the Presidency and the European Parliament, whereby the latter is kept fully informed of developments. But 
whereas such meetings had in the past a certain formality, with the Foreign Minister or Heads of State and Government presenting to the European Parliament its aims for the Presidency, this state of affairs is no longer true. To this end, there has been a marked increase in the number of visits by the Presidency to the European Parliament, with the former no longer just presenting a 'report' at the start of its six-month term of office, but rather being subjected to a more rigorous questioning and examination by the Parliament throughout the Presidency. In practical terms, this has been reflected, particularly since the Amsterdam Treaty of 1997, in each Presidency spending more time with the Parliament than the previous Presidency did.

The increased amount of work which the assumption of the Presidency brings to a member state, and the Permanent Representation in particular, ensures that a great deal of effort is attached to its planning. It is therefore not surprising that a 'Presidency unit' tends to be established within a Permanent Representation at least a year before it assumes the Presidency, while there is a further tendency for staffing levels to increase. The extra burden means that in most cases additional Ministers and officials have to be brought in to the Permanent Representation as national spokesman so that the normal representative can move into the chair. For those that occupy the chair, they have the important task of creating compromises and brokering packages amongst member states, with their role also being crucial to the smooth running of the Presidency. For instance, they have to ensure that topics are properly debated and that individual negotiators (some of whom may have been recently appointed to their position) are fully aware of events.

The shape, nature and speed with which alliances develop depends on the Presidency, its agenda setting role providing an ability to accelerate or decelerate the pace of negotiations. Views are reflected in Presidency texts, with success or failure an important influence on discussion. Much of this work is based on tactical considerations because each country thinks its record as President will be measured by the number of proposals and/or is sues that 
it gets finally settled. In general terms, therefore, member states can be disinclined to spend time on items that they can't settle before their time expires and for which their successor will get the credit. These tactical points of view can, however, merge with the 'neutral' brokering role of the Presidency, which can lead to a conflict of interest. To take an example, if there is a proposal that a Presidency particularly wants to oppose, then it is extremely likely that it will leave it alone because, as the Presidency, it would be its duty to seek a compromise solution.

An exception to this rule is the strong links between Presidencies in the area of foreign policy. At the basic level, this is primarily because of the need to present a 'united' viewpoint on foreign affairs, although that does not mean that all states agree on foreign policy action. In addition to this concern, policy co-ordination between Presidencies was influenced by the consideration that the EU should not just be represented by a small state that happened to hold the office of Presidency. It was with this in mind that the concept of a troika (the preceding, current and succeeding Presidency) was injected into the CFSP section of the Maastricht Treaty so that the EU would be represented by three states. That situation was, however, changed by the Amsterdam Treaty, which provided for the Presidency to be only assisted by the succeeding state. xiii $^{\text {in }}$

In carrying out these various duties, member states are assisted by the Antici Group ${ }^{\text {xiv }}$, which comprises assistants to the Permanent Representatives and a Commission representative. It has the responsibility of organising the proceedings of COREPER 2, especially the agenda, and checks the minutes of previous COREPER meetings so Permanent Representatives can approve them. This obviously has the benefit of ensuring that routine policy matters do not burden COREPER meetings and for that reason allows the greatest amount of time to be spent on crucial topics. ${ }^{\mathrm{xv}}$ Antici meetings therefore play a similar role to the meetings of Cabinet committees in some member states, because they too act as a 
discussion and negotiating forum for topics that are not crucial. In following this structure, Antici meetings - which are chaired by the Presidency Antici - are a useful co-ordinating tool where a Presidency can inform member states of how they intend to tackle particular problems and discover the room for manoeuvre on specific points. And just as this task is performed for routine Coreper meetings, the Antici Group acts as a further linkage between national delegation and Heads of State or Government at European Council meetings. The format of this procedure is that the Presidency Antici takes minutes of the decisions taken in Council and then informs the other Anticis of the negotiations, who then in turn advise national delegations of the developments. This linkage is necessitated by attendance at European Council meetings being limited to Heads of State or Government, Foreign Ministers and the Commission President accompanied by a fellow Commissioner, who is usually the senior Vice-President.

In more recent years member states have been assisted by the Friends of the Presidency Group, which, as its name suggests, was created with the intention of assisting the running of the Council Presidency. But whereas the Antici Group is a formal body that meets on specific days and has certain established rules of conduct, such as at European Council meetings, the intention with the Friends of the Presidency Group was to create a far more informal body. To this extent, the language of the Group was limited to French and English, with the intention of holding meetings when the need occurred. In some senses it mirrors the work of the Antici Group (often including the same officials) and acts as a clearing house for ideas from all participants. One difference is, however, that the Friends of the Presidency Group has become involved in supporting the work of personal representatives during intergovernmental conference (IGC) negotiations. This essentially involves informing the personal representatives of what the main problems are, in what light they can be viewed, and what specific questions arise from them, as well as taking decisions on those matters where 
agreement can be reached. In this context, a great deal of the treaty drafting conducted during the 2000 IGC has been completed by the Friends of the Presidency Group.

\section{Conclusion}

The foregoing analysis has highlighted the role played by Permanent Representations in the EU policy process, while also making comparisons between them and other diplomatic representations. From this it is clear that Permanent Representations play a crucial role in the activities of the EU, acting as a natural linkage point between the interests of member states and the institutions. In examining the primary differences between Permanent Representations and normal Embassies, it is evident that while some of the functions that they perform are similar, such as intelligence gathering, the most significant task for a Permanent Representation is that of negotiation. In this sense, Permanent Representations really do stand apart from other diplomatic postings. This point is further emphasised by the diverse staff that comprises a Permanent Representation as well as the closeness of links between it and national capitals.

While it is possible to compare the role of Permanent Representations, it is a far more difficult task to analyse their effectiveness. One of the reasons for this is the subjective nature of the assignment. This is partly because EU negotiations are not zero sum games; any one negotiation involves a multitude of topics that necessitate an agreement to be brokered. Moreover, each negotiation does not sit alone, but is part of the on going nature of the diplomatic process within the EU. A second factor is that the effectiveness of a Permanent Representation depends on the political objectives that are set by Government. It is possible in some instances for there to be no objectives, which can result in a Permanent Representative saying that 'if we had a position our view would be...' The impact of this is to generally reduce the negotiating influence of a member state, and hence any negotiating 
success for such a nation could be measured as being more significant than that achieved by member states that provided their Permanent Representation with positive instructions.

In the case of Britain there has traditionally been a gap between a highly efficient Government apparatus and the less effective political objectives set by Government. Thus, whereas the British position was even more negative during the Amsterdam Treaty negotiations than it had been in the Maastricht Treaty negotiations, the Permanent Representation was at least provided with clear guidance as to what was and was not achievable during the Amsterdam talks. This was primarily because Government and officials were aware that the IGC ne gotiations had not been given enough attention during the Maastricht talks, which had hindered the ability of negotiators to advance a British position. The fact that the subsequent Amsterdam talks included (for the most part) a Eurosceptic tone, does not take away from the point that the Permanent Representation was given sufficient advice to negotiate on behalf of Britain. Much of this was, of course, altered when Labour was elected prior to the June 1997 Amsterdam European Council, thereby installing a more pro-European outlook. It should therefore be apparent from the above that there can often be a gap between the technical ability of a member state to negotiate and the political objectives that are set. That much of the work of a Permanent Representation is involved in narrowing this gap has once again become apparent during the 2000 IGC negotiations.

This article is based on conversations with officials and Ministers in the UK, Luxembourg, the Netherlands, Belgium, France, the European Commission, the European Parliament and the Council Secretariat. The author is grateful to the assistance they provided, the financial support of the Faculty of Social Sciences and Humanities at Loughborough University and the comments of an anonymous referee.

i This article builds on 'Permanent Representatives to the European Union', Diplomatic Studies Programme Newsletter, Number Four, May 1998, pp.17-19.

ii It only achieved this status in December 1992. All previous decisions on location were provisional.

iii It must hold twelve plenary sessions a year in Strasbourg.

iv The Permanent Representative generally has final say on appointment matters.

${ }^{v}$ So me Embassy staff are involved in matters of trade promotion and may not come from the Foreign Office, as is also true for armed services personnel.

${ }^{v i}$ Article 151, as amended by Article G(46) TEU. The Committee of Permanent Representatives (COREPER) was made official in 1965.

vii See Martin Westlake, The Council of the European Union, Catermill Publishing, London, 1995, and Fiona Hayes-Renshaw and Helen Wallace, The Council of Ministers, Macmillan, Basingstoke, 1997. 
viii Article 151, as amended by Article G(46) TEU, notes that 'A committee consisting of the Permanent Representatives of the Member States shall be responsible for preparing the work of the Council and for carrying out the tasks assigned to it by the Council'.

ix See Fiona Hayes-Renshaw et al, 'The Permanent Representations of Member States to the European Communities', Journal of Common Market Studies, Vol.28, No.2, 1989, pp.119-137.

${ }^{\mathrm{x}}$ The SGCI, reporting to the Prime Minister, provides centralised co-ordination, except for CFSP and budget matters, where the Foreign Ministry and Ministry of Finance dominate the proceedings. At the ministerial level the SGCI is responsible, through the Prime Minister, for policy co-ordination.

xi 'Evidence to the House of Commons Foreign Affairs Committee', The Operation of the Single European Act. Minutes of Evidence. Session 1988-89, 446 (iii), p.45, para.149.

xii The proper name is General Affairs Council.

xiii Orig inally the Treaty provided that the order of the Presidencies should be the alphabetical order of countries, expressed in their own language. For the 12, it was Belgie, Danmark, Deutschland, Ellas, España, France, Ireland, Italia, Luxembourg, Nederland, Portugal and the United Kingdom. The problem with this rotation was that with an even number of countries, half would be condemned to having the Presidency in the second half of the year, when there is only 5 months of work because of the August holiday break (without even taking account of the Christmas break.) In the Spanish/Portuguese Accession Treaty, Article 146 of the EU Treaty was amended so that there should be a further cycle of 12 Presidencies in which each succeeding pair was reversed, i.e. Dan mark, Belgie, Ellas, Deutschland, France, España, Italia, Ireland, Nederland, Lu xe mbourg, United Kingdom and Portugal. When the EU began to seriously think about a common foreign and security policy, it was felt that it would not carry much credibility if a single small member state attempted to represent the Union in external action. The idea of the troika was born, and was put into the CFSP part of the Maastricht Treaty (Article J.5). But this development did not resolve the concern of the larger member states about the composition of certain troikas if the roughly alphabetical system was continued. They did not want the EU to be solely represented by a collection of three small states, or states with little feeling for defence questions. So, in the context of the most recent enlargement, instead of slotting in Österreich, Sverige and Suomi in their proper places in the list, the alphabetical order was completely abandoned with effect from the second half of 1998. The effect of this has been to ensure that there is always one large state in the troika. Finally, and in a development that makes no sense whatsoever of the foregoing, the Amsterdam Treaty (Article J.9) has wholly abandoned the troika for CFSP and substituted a duopoly; i.e. the Presidency is to be assisted by the next state in line only and not also the preceding one.

xiv The Antici Group was named after the Italian Deputy Permanent Representative to the EC, Paulo Antici, who was its first chairman in 1975. It meets on the eve of each Thursday Coreper 2 meeting as part of an effort to establish an agenda for the Permanent Representatives, whom they thereafter inform of the decisions taken.

${ }^{x v}$ The Mertens Group was established in the second half of 1993 to provide the same co-ord ination function as the Antici Group for Coreper 1 and the technical Councils. 